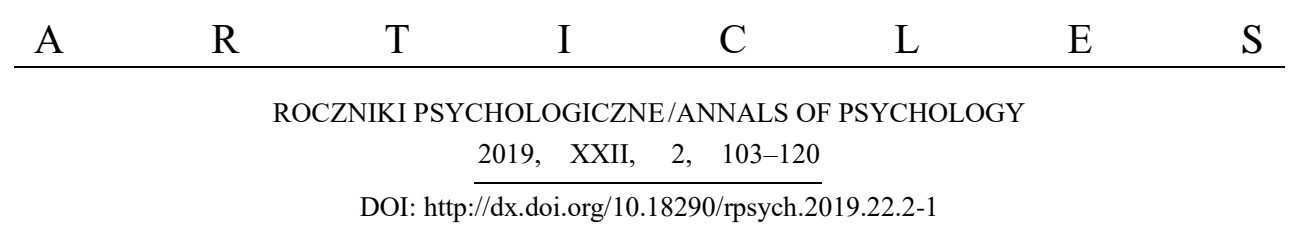

\author{
RAFAŁ LAWENDOWSKI ${ }^{\mathrm{a}}$ \\ ZOFIA MAZUR ${ }^{\mathrm{b}}$ \\ ${ }^{a}$ University of Gdańsk, Poland \\ Institute of Psychology \\ ${ }^{\mathrm{b}}$ The John Paul II Catholic University of Lublin, Poland \\ Institute of Psychology
}

\title{
THE PSYCHOLOGY OF MUSIC IN POLAND: THEORETICAL CONSIDERATIONS AND CURRENT DIRECTIONS IN EMPIRICAL RESEARCH
}

\begin{abstract}
The psychology of music has a long tradition and continues to develop both in Poland and abroad. The current issue of Roczniki Psychologiczne [Annals of Psychology] is devoted to topics related to the scientific study of music, addressed by Polish scholars from different research units. In the current introductory article we aim to describe the context in which the psychological study of music develops. Assuming that the psychology of music is a science dealing relationships between music and human listeners, performers, or composers, we explain the meaning of that notion, presenting the characteristics of such relations. We also describe the beginnings and development of the psychology of music in Poland and abroad, introducing the main goals of this multidisciplinary and integrative science. Finally, we present the contents of the current issue of Roczniki Psychologiczne [Annals of Psychology].
\end{abstract}

Keywords: psychology of music; scientific discipline; theory; research.

Corresponding author: RAFAŁ LAWENDOWSKI - University of Gdańsk, Institute of Psychology, ul. Jana Bażyńskiego 4, 80-309 Gdańsk, Poland; e-mail: r.lawendowski@ug.edu.pl

Disclosure statement: The authors declare no potential conflicts of interest with respect to the research, authorship, and/or publication of this article.

This research was financed by the National Science Centre, Poland, grant no. DEC-2018/ 29/N/HS6/02641. 


\section{INTRODUCTION}

Music is a universal element of human civilization and, just like language, it accompanies every culture, past and present (McDermott \& Hauser, 2005; Sloboda, 2002). Musical instruments appeared very long ago in the phylogenetic development of the homo sapiens species. This is evidenced, for example, by primitive flutes made of swan or griffon vulture bones some 36-38 thousand years ago, discovered by researchers in the Geissenkösterle and Hohle Fels cave in present-day Germany (Conard, Malina, \& Münzel, 2009; d'Errico et al., 2003; Higham et al., 2012). Ever since the ancient times it was believed that the house, the state, as well as the body and the soul cannot exist without music. Moreover, already in ancient China during the reign of the Zhou dynasty (1122-221 BC) issues related to the influence of music on people's attitudes, behaviors, and motivation were studied (Manturzewska, n.d.). Therefore, history not only shows that our ancestors were interested in making and listening to music, but also indicates how early they recognized the importance of influences of music on their lives.

The first aim of this article is to present a review of the literature concerning topics related to the psychology of music, namely: the relations between music and its listeners, performers, and composers as well as the beginnings, characteristics, and development of music psychology in Poland. The other aim is to present the contents of the current issue of Roczniki Psychologiczne [Annals of Psychology].

\section{MUSIC AND ITS LISTENERS, PERFORMERS, AND COMPOSERS}

No introduction to music-related issues should leave the reader without answering the fundamental question: What is music (Rakowski, 2001)? According to Rakowski, what makes the difference between music and non-musical sounds or noise is sound construction and appreciation. Music appears when three conditions are met: (1) a sound structure is created, either in physical material or in imagination; (2) that structure is consciously or subconsciously recognized; and (3) pleasure is derived from that recognition. Similarly, Parker highlights the point that music is produced in our minds, as "the vibrational elements of sound (physics of the cosmos) such as frequency, form, amplitude, and duration are not music to the human until they are neurologically 
transformed to, and interpreted by the brain as pitch, timbre, loudness, and time (the tonal frame)" (Parker, 2000, p. 165; as cited in Parker, 2000). In sum, music is a sound structure that we individually transform, recognize, and react to, also emotionally.

To understand music, one should refer to psychology - the science of the mind, behavior (Parker, 2000), and emotions (Swaminathan \& Schellenberg, 2015). Psychology can analyze not only music listeners but also performers or composers who produce music and the two-way relations between them and the music (Manturzewska, 1990b, p. 13). Below we introduce the aspects of the relationship between music and the listening environment; we also characterize the relation between music and its performers.

The last decades have brought the popularity of music on an unprecedented scale. According to research conducted in 2018, people spend around 17.8 hours per week listening to music (IFPI, 2018). As David Hargreaves and Adrian North noted in the introduction to their classic work, The social psychology of music (1997), it was the development of technology and the popularization of media that effectively contributed to the growing availability of music. Currently, we can listen to songs from multiple music streaming services such as YouTube, iTunes, Spotify, television, or radio. Thus, progress has been observed regarding its applications in everyday life (IFPI, 2019).

Interestingly, nowadays people gather around music not only in the virtual world and digital communities. Music accompanies the performance of many activities, such as driving a car, visiting commercial spaces, cinemas, and restaurants; it is with us at the work place, in the hairdresser's waiting room, or at a football stadium (North \& Hargreaves, 1999). Just as in remote times, there is still a strong desire in people to participate in collective musical events. One proof of that is summer music festivals, which gather many thousands of participants. In a similar vein, Andrew Lloyd Webber's musical The Phantom of the Opera has been seen so far by 140 million people in 35 countries around the world (The Really Useful Group, 2016).

While we intentionally or involuntarily experience music in all these virtual and natural contexts, it continuously influences our lives. We choose to listen to music in order to regulate arousal and mood, to achieve self-awareness, to express social relatedness, or for other reasons (Lawendowski \& Besta, 2018; Schäfer, Sedlmeier, Städtler, \& Huron, 2013). Music also has an impact on our thoughts and feelings unconsciously and without our control; for example, it affects our memory and product choice during shopping (North, Sheridan, \& Areni, 2016), influences the effectiveness of studying (Mensink \& Dodge, 2014), 
or makes us ready to spend more time waiting (North \& Hargreaves, 1999). Given these special functions, music is often utilized in therapeutic efforts to improve psychological and physical health (e.g., Aalbers et al., 2017). On the one hand, it becomes an element available in most areas of life that we, as recipients, experience without awareness, or as an object of conscious reflection, a source of intellectual and emotional pleasure. On the other hand, for music performers, it is a form of education, professional activity, a means of achieving professionalism and virtuosity, or simply a hobby.

Performing music might result in many changes in our abilities, behavior, and emotions, as well as in our brain. Taking musical lessons can improve memory, musical skills, as well as language and mathematical abilities (Schellenberg, 2006). The effects of acquiring skills in playing a musical instrument are also evident in the brain structure, which is different in musicians and changes over the course of learning (e.g., Schlaug, 2008). Musicians experience a range of feelings and emotions as a result of their musical education; for instance, they feel bored or frustrated during long practice sessions or anxious before a music exam, but there are also feelings of happiness and satisfaction after the completion a difficult task (Mazur \& Łaguna, 2019).

Musical students, professional performers, and composers are mentioned here to show that it is not only music that influences our lives, but it is also wewith our individual characteristics such as musical potential (Kemp \& Mills, 2002) or self-efficacy (McPherson \& McCormick, 2006), with our emotions and motivations (Hallam, 2016; O'Neill \& McPherson, 2002), and within a particular environment (Gembris \& Davidson, 2002) - that influence music. We may ask under what conditions we can attain high musical skills and perform music on a high level, or what we need to compose a piece that will be valued by society. This imposes a relationship between music and humans can be seen as bidirectional.

The intensity with which people use music and their strong commitment to music on the emotional (Gabrielsson, 2001), cognitive, professional, and financial levels (Hargreaves \& North, 1997; North \& Hargreaves, 2008) encourages a more careful look at the problems of this two-way relationship between people and music. The scientific discipline that explores this area is the psychology of music. ${ }^{1}$ Below we briefly discuss how the psychology of music emerged,

\footnotetext{
${ }^{1}$ The term "psychology of music" is often used interchangeably with "music psychology" (Ockelford, 2016), but sometimes "the psychology of music" is treated as a subdiscipline of the wider discipline of "music psychology" (Eagle, 1996; as cited in Hodges, 2003). In this article we treat these two terms as synonyms.
} 
presenting its integrative and multidisciplinary character, main purposes, and directions.

\section{INTRODUCING THE SCIENCE OF MUSIC PSYCHOLOGY}

\section{The emergence of the field of music psychology}

The psychology of music has more than a century of scientific tradition (Thaut, 2016). The fathers of scientific psychology — Carl Stumpf and Carl Seashore - are also often considered the pioneers of the psychology of music (Manturzewska, n.d.; 1990b; Thaut, 2016; Wertheimer, 2012). Their scientific work devoted to the perception of sounds paralleled the emergence of psychology as a separate field of science.

In 1883 Stumpf was the first who applied modern scientific methods such as experimental testing, hypothesizing, and statistical analysis in the field of music psychology (Thaut, 2016). He proposed several aural tests to assess musical abilities that music teachers might apply to select pupils (Hallam, 2009). Stumpf was especially interested in perceptions of consonance and dissonance, which is evident in his publication Tonpsychologie (Psychology of Tones). He was also an accomplished musician who played six musical instruments very well (Wertheimer, 2012).

In 1919, Seashore started his line of research linking psychology and psychophysics, i.e., psychoacoustics, in regard to music (Thaut, 2016). He developed a psychometric test designed to assess acoustic acuity. Seashore's test consists of acoustic stimulus pairs; the subjects have to decide if two stimuli are the same or different in terms of pitch, timbre, duration, or rhythmic pattern structure. There were also other psychologists apart from Stumpf and Seashore, such as Herman von Helmholtz, who contributed to the development of the psychology of music as a science. At the beginning, this discipline was focused primarily on the acoustic or physical determinants of music perception.

\section{The multidisciplinarity and integrity of the science of music}

From the very beginning until the present day, psychologists of music have considered a complex, two-sided relation between a person (the recipient, the performer, the creator) and music to be part of their scientific research area (Manturzewska, 1990b). The term "psychology of music" has been used to de- 
scribed as a strongly multidisciplinary and interdisciplinary field pertaining to the phenomenon of music. This view was shared by some of the pioneering leaders, such as Seashore or Eagle (Eagle, 1996; Seashore, 1938; as cited in Hodges, 2003) and is also present today (Hodges, 2003; Ockelford, 2016). Therefore, to understand music we have to take into account the input from many different disciplines such as psychology, anthropology, musicology, pedagogy, sociology, medicine, and music therapy, as well as acknowledge biological, physical, aesthetic, and philosophical perspectives (Hodges, 2003; Manturzewska, n.d., 1990b).

In addition, the interdisciplinary character of the psychology of music can also be seen in research. Firstly, research in the psychology of music is intertwined with knowledge from the field of psychobiology; for example, it concerns the effects of music on the human immune system (Fancourt, 2016). Secondly, this discipline relates to neuropsychology, because, for example, it links brain areas to music perception and production (Cameron \& Grahn, 2016). Thirdly, music psychology draws upon social psychology, as it focuses on the link between music and social relationships (Loeb, Reed, Golinkoff, \& Hirsh-Pasek, 2019; Schäfer \& Eerola, 2018). Fourthly, the discipline also relies on insights from developmental and educational psychology, for example, studies on the life-span development of musicians (Manturzewska, 1990a; McPherson, 2005). Finally, knowledge provided by motivational and personality psychology is used, for example in studies on self-efficacy and its impact on musical achievements (McPherson \& McCormick, 2006).

Current psychology of music leaves a wide space for multidisciplinarity and for the integration of the views held by representatives of the above fields. This is evident in the aims and contents of key journals devoted to this area of research, namely: Psychology of Music, Music Perception, Musicae Scientiae, and Psychomusicology (for a review, see Ockelford, 2016). For example, the aim of Psychology of Music is to "increase scientific understanding of all psychological aspects of music and music education" and to publish "studies on listening, performing, creating, memorizing, analysing, learning and teaching as well as applied social, developmental, attitudinal and therapeutic studies" (Psychology of Music, 2019). The call for the integration of science is highlighted in this journal, as "special emphasis is placed on studies, which address the interface between music psychology and music education" (Psychology of Music, 2019). The analysis of the contents of Psychology of Music shows that these aims are being fulfilled; authors draw on a variety of disciplines and integrate multiple scientific perspectives (Figure 1; Ockelford, 2016). 


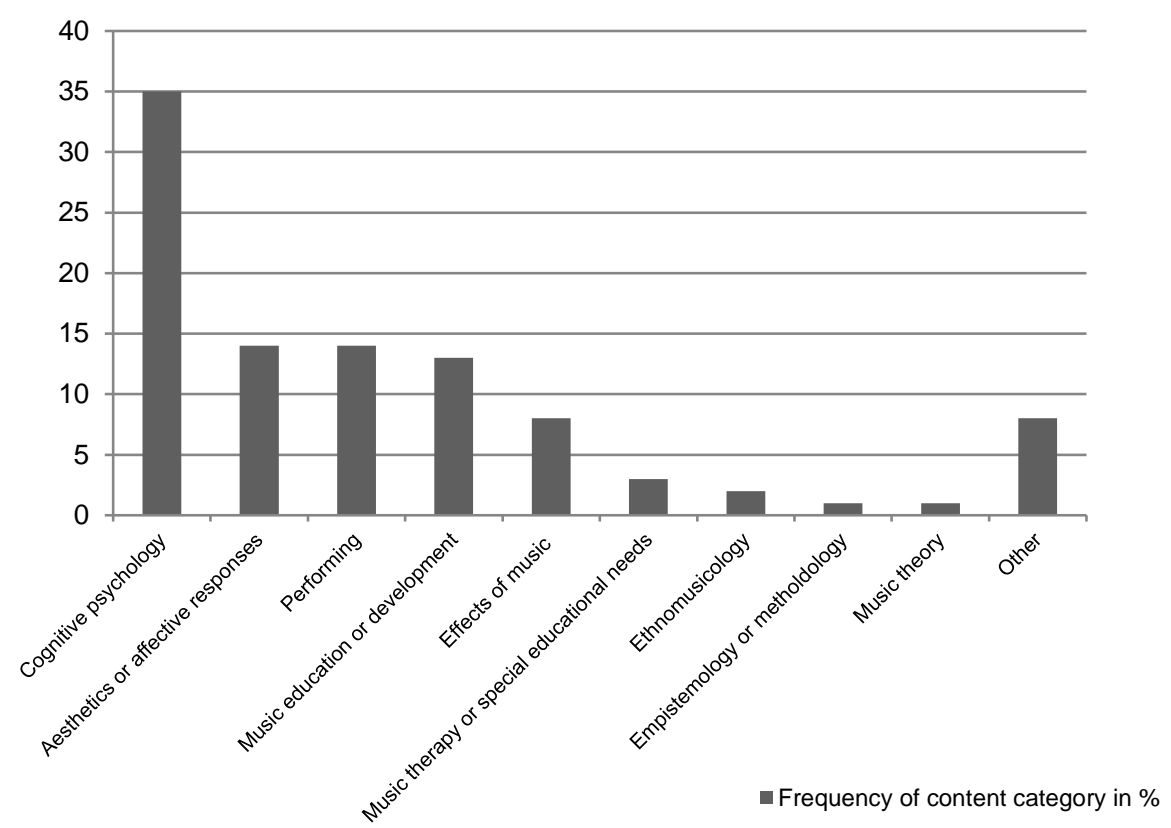

Figure 1. The contents of the 679 papers published between 1973 and the first half of 2014 in Psychology of Music (in percentages; based on analysis reported in Ockelford, 2016).

Some scholars see this hybridization of music psychology science as a strength, suggesting that it results in a rich cross-fertilization of ideas and research rooted in a range of epistemologies and methodologies (Ockelford, 2016). Others point to the conceptual cross-pollination that is problematic (e.g., by acknowledging a conflict in the way in which music psychology and theory of music describe their material and in what they extract and evaluate as significant findings); and to the relative purity of purpose and procedure characteristic of a single discipline.

What connects music psychologists of different specialties is the attempt to capture the general patterns of behavior, experiences, processes, and psychological properties related to music. Of course, individual differences in this area are also analyzed, as well as developmental changes that we are subject to as listeners, musicians, or music students (Manturzewska, 1990b). The aim of music psychology is to describe and explain the phenomena linked to the performance, creation, learning, and listening to music. It is also important to understand, in the context of social sciences, musical preferences and attitudes as well as the broad spectrum of ways in which music has an impact on people. Thus, the psy- 
chology of music addresses issues related to the perception of music, musical development, and musical emotions, as well as to more practical issues, such as psychological work with performers and the use of music in marketing. In the proposed scientific approach, music is analyzed from the perspective of social interaction (Manturzewska, 1990b), musical education (Hodges, 2003), as well as its medical and therapeutic applications (as postulated in Thaut, 2016).

Psychologists of music analyze the biological, personality, and temperamental determinants of reactions to music (Cattell \& Saunders, 1954; Kantor-Martynuska, 2009; Kemp, 1997; Kopacz, 2005; Lawendowski, 2011; Litle \& Zuckerman, 1986; Rentfrow \& Gosling, 2003) using a sociocultural perspective. Also, music psychology seeks to know the different ways in which a person engages in music (through its creation, performance, and reception) and tries to explain the psychological mechanisms underlying these processes. The use of a sociocultural perspective implies that the social psychology of music analyzes and places every musical behavior in various possible cultural and social contexts.

To sum up, music is understood not only as a form of art, a mass media product, an element of advertising, or an indicator of social change on a global scale, but above all as a form of activity, a general human development dimension, and an important component of social life. More and more often attention is paid to the importance of music for the quality of human life, but also to the environmental context, the generational effect, and the impact of social factors on the course of musical activities. A special aspect of music psychology is the practical dimension of the scientific research, for which real problems connected with the functioning of a human being in the musical space become an inspiration (Thaut, 2016).

We can see the confirmation of these words even in the title of the book by North and Hargreaves (2008)—The social and applied psychology of music. As regards the interpretation of this book title, the first thoughts are probably about music therapy or music education. However, using the knowledge from the field of music psychology was of interest to representatives of fields such as the music industry, advertising, film, work places, trade, politics, or the military. This is understandable, since music can favor or hinder the performance of various life activities and influence people's psychological well-being, health, and behavior. In this context, the psychology of music and the specifics of its development in Poland deserve special attention. Below we describe the history of the discipline in our country, mentioning some of the important scholars and institutions involved in its development. 


\section{THE DEVELOPMENT OF MUSIC PSYCHOLOGY IN POLAND}

Importantly, the psychology of music has a relatively long and vibrant tradition in Poland (Manturzewska, n.d., 1990b). The first research in the field of music psychology was carried out in the interwar period at the University of Lwów (now Lviv, Ukraine; research into the development of musicality in young children) and the Jagiellonian University (research on the usefulness of the musical ability test in education). Immediately after the Second World War, there was a dynamic development of music psychology in Poland.

In 1956, the first research unit in the field of music psychology was established in Warsaw under the guidance of Maria Manturzewska. It was called the Pedagogical Center of Art Schools (PCAS) ${ }^{2}$ and it integrated Polish psychologists and educationalists from various schools in Warsaw, Wrocław, Cracow, and Poznan (the research team included, among others, Manturzewska, Słoniewska, Dronsejko, Jędrzejewska, Horbulewicz, and Malinowska; Manturzewska, 1990b). It was in this center that the first scientific conferences dedicated to the psychology of music were organized. In 1956-59, PCAS obtained almost all available measurement tools for music psychology from abroad thanks to Mieczysław Choynowski; they were then adapted to the Polish context.

Apart from working on psychometric tests for music psychology, the Polish research team from PCAS focused on applied psychology for music schools (Manturzewska, 1990b). They prepared diagnostic tools for assessing children's musical abilities to be used by music school teachers. In 1958 they also initiated the first psychological and pedagogical counseling centers for students from music schools in Warsaw, and Poznan. Soon afterwards such centers were also established in Cracow, Wrocław, Gdańsk, and Katowice.

What is particularly noteworthy is the activity of the Department of the Psychology of Music (DPM) ${ }^{3}$ at the Fryderyk Chopin University of Music (FCUM) ${ }^{4}$ in Warsaw (Jankowski, 2011). Since 1975, this research unit has been conducting research as well as teaching, training, and consulting activities (Manturzewska,

2 The Polish name and abbreviation is Centralny Ośrodek Pedagogiczny Szkolnictwa Artystycznego (COPSA).

${ }^{3}$ This research unit has changed its names and character many times; at the beginning it was called the Institute of Pedagogy of Music, later the Department, Laboratory, or Section of the Psychology of Music.

${ }^{4}$ When the research unit was created, the name of the university was Fryderyk Chopin Music Academy. 
n.d.; 1990b). The scientific interest of the people involved in the department concerned the following issues: people's musical development, musicians' life course and artistic and professional development, the psychological aspects of musical performance, the psychological and environmental and biographical determinants of success in musical education and musical activity, music in the lives of people with special mental and educational needs, psychometrics and musical psychodiagnosis (the measurement and assessment of musical attitudes, preferences, abilities, and achievements).

Maria Manturzewska, a specialist in the field, highly regarded both in Poland and abroad, was involved in the development of Polish music psychology from the very beginning. Her research on the determinants of musical achievements (Manturzewska, 1968, 2014) and the world's first research on musicians' course of life and professional careers (Manturzewska, 1990a) holds an important place in the history of Polish and world music psychology. Among other things, she also made her mark on psychological counseling in Polish music schools.

In 1990, an influential book for the Polish psychology of music was published, edited by Maria Manturzewska and Halina Kotarska-Wybrane zagadnienia z psychologii [Selected issues in the psychology of music]. It features contributions from DPM's employees and presents the most important issues of music psychology in accordance with the state of knowledge at the time of its publication. It also describes the achievements of the DPM. Currently, the book is a classic item in the Polish literature in the field of music psychology.

Many other scholars actively shaped music psychology in Poland. Manturzewska and Kotarska (1990) mention 25 prominent Polish psychologists, but today, after 30 years, we must acknowledge that this number is substantially larger. It is worth mentioning a few names of prominent Polish scientists involved in the field and their main research focus. Andrzej Rakowski is known for his influential experimental psychoacoustic research in the field of music cognition (e.g., Rakowski, 1990, 2001; Rakowski \& Rogowski, 2011). Kacper Miklaszewski analyzed the process of learning music and preparing songs for public performance and prepared a conception of criteria for the assessment of music performance (e.g., Miklaszewski, 1989, 2006; Zielinska \& Miklaszewski, 1992). Barbara Kamińska worked in DPM, conducted pedagogical and musical research into the musical development of young children and the psychological determinants of vocal skills (e.g., Kamińska, 1997). Kinga Lewandowska contributed to the knowledge about music therapy and musical development in children (e.g., Lewandowska, Lewandowska, \& Sołowiej, 1985; Lewandowska, 1978, 2007). Jolanta Kępińska-Welbel worked on issues linked to stage fright in musicians 
and on the theoretical and empirical foundations of psychological counseling for musicians and musically gifted young people (e.g., Kepinska-Welbel, 1991). Elżbieta Galińska and Ewa Klimas-Kuchtowa also developed the field of music therapy (e.g., Galińska, 2015; Galińska \& Aranowska, 2004; Klimas-Kuchtowa, 1993; Klimas-Kuchtowa \& Chudzikiewicz, 2013). Małgorzata Chmurzyńska investigated issues related to the artistic and professional development of musicians and factors fostering the success in music as well as in the functioning of music education (e.g., Chmurzyńska, 2014; Chmurzyńska \& Kamińska, 2006).

Research and implementation programs in the field of music psychology and music pedagogy put into effect by the staff of the DPM in Warsaw have always been associated with the needs of musical and pedagogical practice in our country (e.g., music and psychological diagnostics, music education and upbringing; Manturzewska, 1990b). The initiatives of DPM also put focus on the integration of scholars from different scientific units. In the years 2001-2006, three editions of postgraduate studies in music psychology were conducted at the FCUM. This research unit served as a center for Polish music psychologists. It has been in touch with the majority of academic centers in Poland, where music psychology is available and where scientific research in this area is conducted. On the scientific map, there are, for example, the following places and specialists: the Academy of Music in Poznań (Małgorzata Sierszeńska-Leraczyk, who investigates cognitive, personality, and environmental determinants of musical development and musical achievements), the University of Gdańsk (Rafał Lawendowski, who specializes in the social psychology of music), the Pedagogical University of Kraków (Julia Kaleńska-Rodzaj, who analyzes the issues of psychological preparation of musicians for public performance and the conditions of success in the field of music), the Kazimierz Wielki University in Bydgoszcz (Anna Nogaj, who provides psychological counseling for students and conducts research in this field, focused on the problems of artistic development).

Recently, the Psychomuzy conference, which took place in April 2018 at the University of Silesia in Katowice, played an important role in the consolidation of the Polish music psychology community. Its purpose was to show the abundance of research in the field and the diversity of music psychology in Poland. The topics discussed at the conference included both basic knowledge from various areas of music psychology research as well as practical skills in using this knowledge in various areas of musical life (Chełkowska-Zacharewicz, 2018). The conference was attended by such eminent specialists as Jane Ginsborg, Richard Parncutt, and John Sloboda. The event was under the auspices of the European Society for Cognitive Sciences of Music (ESCOM, 2019) - an interna- 
tional association supporting theoretical, experimental, and applied research in cognitive science in the field of music. During this conference, a living and cooperating milieu of theoreticians and practitioners initiated the process of establishing a scientific society called the Polish Society of Music Psychology.

\section{CONCLUSIONS AND THE CONTENT OF CURRENT ISSUE OF ROCZNIKI PSYCHOLOGICZNE [ANNALS OF PSYCHOLOGY]}

Research into the application of knowledge concerning the musical dimension of human mental life has been intensifying in recent years. The dynamics of the development of research in Polish music psychology (publications in the most prestigious professional and psychological journals, scientific grants acquired, the organization of international scientific conferences and active participation in them, doctoral dissertations written on the subject) thus deserves detailed studies and in-depth analysis. At the beginning of music psychology in Poland, there were primarily two lines of research: one was studies on the process of listening to and experiencing music; the other was psychometric research on musical abilities, their development, and measurement. Today, the diversity of research topics is vast and difficult to classify unambiguously.

In the face of the huge changes that affect the psychology of music, and seeing the variety of research conducted within its framework, we wish to recommend the special issue of Roczniki Psychologiczne [Annals of Psychology] dedicated to this scientific discipline. The main objective of the thematic issue is to present the latest developments in the field of music psychology in Poland. An additional goal of this publication is to draw attention to the literature in the field of music psychology as well as to inspire psychologists, educationalists, sociologists and therapists to engage in scientific exploration and find new paths within this research area. We hope that the proposed articles will convince the readers that the field of music psychology is intensively developing and that the studies conducted in its scope have important practical and theoretical implications for people's psychological functioning, at the same time becoming an inspiration for further research projects.

The current issue includes scholarly articles of Polish music psychologists. The authors invited to contribute present not only empirical results but also theoretical considerations and their consequences for psychological theory and practice. Thus, their contributions help to better understand the mechanisms of the impact of music on the body and people's psychological functioning. 
The first article in this issue concerns the nature and structure of music (Podlipniak, 2019, pp. 121-134). The author confronts us with several claims popular in musicology, such as the notion that music exists outside the mind and the idea that intervals can be described in mathematical proportions. Having a closer look on the nature of music and knowing that it is clearly a product of the mind, we can shift to the issue of music's influence. The next two articles address this topic with regard to the influence of music on the listeners. The second article relates to the influence of music on health, presenting the current directions in research on music therapy for preterm infants and their parents (Bieleninik \& Ghetti, 2019, pp. 135-150). The third article concerns the impact of music from the Lord of the Rings movies on people's thoughts and feelings, while also comparing the composer's aims with the results actually achieved (Chełkowska-Zacharewicz \& Paliga, 2019, pp. 151-175). The last article relates to the relation between performing musicians and music. It presents the results of empirical research on the relationship between the newly developed construct of study addiction and examination stress among musicians from Polish music academies (Atroszko, Wróbel, Bereznowski, \& Lawendowski, 2019, pp. 177-192).

In her article "Psychology of Music as a Scientific Discipline," which presents the origins of the Polish psychology of music, Manturzewska (n.d.) concludes that there is high demand for music psychologists in Poland. The author wrote these words many years ago, but they remain valid today. As the editors of the current issue of Roczniki Psychologiczne [Annals of Psychology], we hope that this publication will encourage our readers to actively explore the presented subject matter.

\section{REFERENCES}

Aalbers, S., Fusar-Poli, L., Freeman, R. E., Spreen, M., Ket, J. C., Vink, A. C., . . Gold, C. (2017). Music therapy for depression. Cochrane Database of Systematic Reviews, 11, CD004517. https://doi.org/10.1002/14651858.CD004517.pub3

Atroszko, P. A., Wróbel, W. K., Bereznowski, P., \& Lawendowski, R. (2019). The relationship between study addiction and examination stress among students of music academies. Roczniki Psychologiczne [Annals of Psychology], 22(2), 177-192. doi: 10.18290/rpsych.2019.22.2-5

Bieleninik, Ł., \& Ghetti, C. M. (2019). Music therapy for preterm infants and their parents: A path forward for research in Poland. Roczniki Psychologiczne [Annals of Psychology], 22(2), 135-150. doi: 10.18290/rpsych.2019.22.2-3

Cameron, D. J., \& Grahn, J. A. (2016). The neuroscience of rhythm. In S. Hallam, I. Cross, \& M. Thaut (Eds.), The Oxford handbook of music psychology ( $2^{\text {nd }}$ ed., pp. 357-368). Oxford: Oxford University Press. 
Cattell, R. B., \& Saunders, D. R. (1954). Musical preferences and personality diagnosis: I. A factorization of one hundred and twenty themes. The Journal of Social Psychology, 39(1), 3-24. https://doi.org/10.1080/00224545.1954.9919099

Chełkowska-Zacharewicz, M. (2018). Program i streszczenia [Program and abstracts]. Retrieved June 29, 2019, from the website of PsychoMuzy 2018. International Music Psychology Conference in Katowice. Retrieved from http://www.psychomuzy.us.edu.pl/program/

Chełkowska-Zacharewicz, M., \& Paliga, M. (2019). Music emotions and associations in film music listening: The example of leitmotifs from The Lord of the Rings movies. Roczniki Psychologiczne [Annals of Psychology], 22(2), 151-175. doi: 10.18290/rpsych.2019.22.2-4

Chmurzyńska, M. (2014). Style nauczania i kompetencje psychopedagogiczne nauczycieli instrumentu ze szkół muzycznych I stopnia [Teaching styles and psychopedagogical competences of instrumental teachers from elementary music schools]. In R. Lawendowski \& J. Kaleńska-Rodzaj (Eds.), Psychologia muzyki. Wspótczesne konteksty zastosowań [The psychology of music. Current contexts of application] (pp. 93-109). Gdańsk: Harmonia Universalis.

Chmurzyńska, M., \& Kamińska, B. (2006). Ocenianie wykonań muzycznych [The evaluation of music performances]. Warsaw: The Fryderyk Chopin Academy of Music.

Conard, N. J., Malina, M., \& Münzel, S. C. (2009). New flutes document the earliest musical tradition in southwestern Germany. Nature, 460(7256), 737-740. https://doi.org/10.1038/ nature 08169

d'Errico, F., Henshilwood, C., Lawson, G., Vanhaeren, M., Tillier, A.-M., Soressi, M., . . Julien, M. (2003). Archaeological evidence for the emergence of language, symbolism, and music - an alternative multidisciplinary perspective. Journal of World Prehistory, 17(1), 1-70. https://doi.org/10.1023/A:1023980201043

ESCOM. (2019). European Society for the Cognitive Science of Music [website]. Retrieved from https://www.escom.org/

Fancourt, D. (2016). An introduction to the psychoneuroimmunology of music: History, future collaboration and a research agenda. Psychology of Music, 44(2), 168-182. https://doi.org/ $10.1177 / 0305735614558901$

Gabrielsson, A. (2001). Emotions in strong experiences with music. In P. N. Juslin \& J. A. Sloboda (Eds.), Music and emotion: Theory and research (pp. 431-449). New York, NY, US: Oxford University Press.

Galińska, E. (2015). Music therapy in neurological rehabilitation settings. Psychiatria Polska, 49(4), 835-846.

Galińska, E., \& Aranowska, E. (2004). Metodologiczne podstawy analizy stylu komunikacji muzycznej [Methodological basis for the analysis of musical communication style]. Przeglad Psychologiczny, 47(4), 327-344.

Gembris, H., \& Davidson, J. W. (2002). Environmental influences. In R. Parncutt \& G. E. McPherson (Eds.), The science and psychology of music performance. Creative strategies for teaching and learning (pp. 17-30). Oxford: Oxford University Press.

Hallam, S. (2009). The role of psychology in music education. The Psychologist, 22, 1016-1017.

Hallam, S. (2016). Motivation to learn. In S. Hallam, I. Cross, \& M. Thaut (Eds.), The Oxford handbook of music psychology ( $2^{\text {nd }}$ ed., pp. 479-492). Oxford: Oxford University Press.

Hargreaves, D. J., \& North, A. C. (Eds.) (1997). The social psychology of music. Oxford: Oxford University Press. 
Higham, T., Basell, L., Jacobi, R., Wood, R., Ramsey, C. B., \& Conard, N. J. (2012). Testing models for the beginnings of the Aurignacian and the advent of figurative art and music: The radiocarbon chronology of Geißenklösterle. Journal of Human Evolution, 62(6), 664-676. https://doi.org/10.1016/j.jhevol.2012.03.003

Hodges, D. A. (2003). Music psychology and music education: What's the connection? Research Studies in Music Education, 21(1), 31-44. https://doi.org/10.1177/1321103X030210010301

IFPI. (2018). Music consumer insight report 2018. Retrieved from https://www.ifpi.org/down loads/Music-Consumer-Insight-Report-2018.pdf

IFPI. (2019). IFPI global music report. Retrieved from https://www.ifpi.org/downloads/GMR 2019.pdf

Jankowski, W. (2011). Relacje psychologii muzyki z edukacja muzyczna w dorobku i zadaniach Katedry Psychologii Muzyki UMFC w Warszawie [The relations between the psychology of music and music education in the heritage and tasks of the Department of the Psychology of Music at FCUM in Warsaw]. Retrieved from http://docplayer.pl/13532186-Relacje-psy chologii-muzyki-z-edukacja-muzyczna-w-dorobku-i-zadaniach-katedry-psychologii-muzykiumfc-w-warszawie.html

Kamińska, B. (1997). Kompetencje wokalne dzieci i młodzieży-ich poziom, rozwój $i$ uwarunkowania [Vocal competences of children and adolescents - their level, development, and determinants]. Warsaw: The Fryderyk Chopin Academy of Music.

Kantor-Martynuska, J. (2009). The listener's temperament and perceived tempo and loudness of music. European Journal of Personality, 23(8), 655-673. https://doi.org/10.1002/per.734

Kemp, A. E. (1997). Individual differences in musical behaviour. In D. J. Hargreaves \& A. C. North (Eds.), The social psychology of music (pp. 25-45). Oxford: Oxford University Press.

Kemp, A. E., \& Mills, J. (2002). Musical potential. In R. Parncutt \& G. E. McPherson (Eds.), The science and psychology of music performance: Creative strategies for teaching and learning (pp. 3-16). Oxford: Oxford University Press.

Kepinska-Welbel, J. (1991). Psychological counseling in music schools in Poland. European Journal of High Ability, 2(1), 86-90.

Klimas-Kuchtowa, E. (1993). Creative thinking as a predictor of achievement in music. European Journal of High Ability, 4(1), 6-10.

Klimas-Kuchtowa, E., \& Chudzikiewicz, I. (2013). Autonomia czy integralność zdolności muzycznych na tle innych funkcji poznawczych [Autonomy or integrity of musical abilities in the light of other cognitive functions]. Zeszyty Psychologiczno-Pedagogiczne Centrum Edukacji Artystycznej, 1, 45.

Kopacz, M. (2005). Personality and music preferences: The influence of personality traits on preferences regarding musical elements. Journal of Music Therapy, 42(3), 216-239. https:// doi.org/10.1093/jmt/42.3.216

Lawendowski, R. (2011). Osobowościowe uwarunkowania preferencji muzycznych w zależności od wieku [Personality determinants of music preferences according to age]. Kraków: Oficyna Wydawnicza "Impuls."

Lawendowski, R., \& Besta, T. (2018). Is participation in music festivals a self-expansion opportunity? Identity, self-perception, and the importance of music's functions. Musicae Scientiae, online first, 1-21. https://doi.org//10.1177/1029864918792593 
Lewandowska, B., Lewandowska, K., \& Sołowiej, J. (1985). Techniki stymulacyjne i terapeutyczne dla dzieci i młodzieży [Technics of stimulation and therapy for children and adolescents]. Gdańsk: Uniwersytet Gdański.

Lewandowska, K. (1978). Rozwój zdolności muzycznych u dzieci w wieku szkolnym [The development of musical abilities in school-aged children]. Warsaw: Wydawnictwa Szkolne i Pedagogiczne.

Lewandowska, K. (2007). Muzykoterapia dziecięca: Zbiór rozpraw z psychologii muzycznej dziecka i muzykoterapii dziecięcej ( $3^{\text {rd }}$ ed.) [Music therapy for children: Collection of issues from child psychology of music and music therapy for children]. Gdańsk: Kinga Lewandowska.

Litle, P., \& Zuckerman, M. (1986). Sensation seeking and music preferences. Personality and Individual Differences, 7(4), 575-578. https://doi.org/10.1016/0191-8869(86)90136-4

Loeb, D., Reed, J., Golinkoff, R. M., \& Hirsh-Pasek, K. (2019). Tuned in: Musical rhythm and social skills in adults. Psychology of Music, 0305735619850880. https://doi.org/10.1177/ 0305735619850880

Manturzewska, M. (1968). Z badań nad ocenami wykonawstwa muzycznego wydawanymi przez ekspertów muzycznych [Research on the evaluation of music performance by musical experts]. Zeszyty Naukowe. Warszawa: PWSM, (4), 113-116.

Manturzewska, M. (1990a). A biographical study of the life-span development of professional musicians. Psychology of Music, 18(2), 112-139. https://doi.org/10.1177/0305735690182002

Manturzewska, M. (1990b). Psychologia muzyki-kierunki i etapy rozwoju [The psychology of music_-directions and stages of development]. In M. Manturzewska \& H. Kotarska (Eds.), Wybrane zagadnienia z psychologii muzyki [Selected issues in the psychology of music] (pp. 11-24). Warsaw: Wydawnictwa Szkolne i Pedagogiczne.

Manturzewska, M. (2014). Psychologiczne wyznaczniki powodzenia w studiach muzycznych [Psychological determinants of success in musical studies] $\left(2^{\text {nd }}\right.$ ed.). Warsaw: Centre for Artistic Education, The Fryderyk Chopin University of Music.

Manturzewska, M. (n.d.). Psychology of music as a scientific discipline [Unpublished manuscript].

Manturzewska, M., \& Kotarska, H. (1990). Wybrane zagadnienia z psychologii muzyki [Selected issues in the psychology of music]. Warsaw: Wydawnictwa Szkolne i Pedagogiczne.

Mazur, Z., \& Łaguna, M. (2019). The role of affect in practicing a musical instrument: A systematic review of the literature. Psychology of Music, 47(6), 848-863. https://doi.org/ $10.1177 / 0305735619861831$

McDermott, J., \& Hauser, M. (2005). The origins of music: Innateness, uniqueness, and evolution. Music Perception: An Interdisciplinary Journal, 23(1), 29-59. https://doi.org/10.1525/ mp.2005.23.1.29

McPherson, G., \& McCormick, J. (2006). Self-efficacy and music performance. Psychology of Music, 34(3), 322-336. https://doi.org/10.1177/0305735606064841

McPherson, G. E. (2005). From child to musician: Skill development during the beginning stages of learning an instrument. Psychology of Music, 33(1), 5-35. https://doi.org/10.1177/ 0305735605048012

Mensink, M. C., \& Dodge, L. (2014). Music and memory: Effects of listening to music while studying in college students. Retrieved from https://minds.wisconsin.edu/handle/1793/77348

Miklaszewski, K. (1989). A case study of a pianist preparing a musical performance. Psychology of Music, 17(2), 95-109. https://doi.org/10.1177/0305735689172001 
Miklaszewski, K. (2006). Koncepcja kryteriów oceny wykonawstwa muzycznego [The conception of criteria for music performance evaluation]. In M. Chmurzyńska \& B. Kamińska (Eds.), Ocenianie wykonań muzycznych [The evaluation of music performances] (pp. 77-93). Warsaw: The Fryderyk Chopin Academy of Music.

North, A. C., \& Hargreaves, D. J. (1999). Can music move people?: The effects of musical complexity and silence on waiting time. Environment and Behavior, 31(1), 136-149. https://doi.org/10.1177/00139169921972038

North, A. C., \& Hargreaves, D. (2008). The social and applied psychology of music. New York: Oxford University Press.

North, A. C., Sheridan, L. P., \& Areni, C. S. (2016). Music congruity effects on product memory, perception, and choice. Journal of Retailing, 92(1), 83-95. https://doi.org/10.1016/j.jretai. 2015.06.001

Ockelford, A. (2016). Beyond music psychology. In S. Hallam, I. Cross, \& M. Thaut (Eds.), The Oxford handbook of music psychology (2 ${ }^{\text {nd }}$ ed.). Oxford: Oxford University Press. https://doi.org/10.1093/oxfordhb/9780198722946.013.52

O’Neill, S., \& McPherson, G. E. (2002). Motivation. In R. Parncutt \& G. E. McPherson (Eds.), The science and psychology of music performance. Creative strategies for teaching and learning (pp. 31-46). Oxford: Oxford University Press.

Parker, O. G. (2000). Music cognition: The relationship of psychology and music. Presented at the International Conference on Music Perception and Cognition, Keele, UK. Retrieved from https://www.escom.org/proceedings/ICMPC2000/poster3/Parker.htm

Podlipniak, P. (2019). The neo-Pythagorean view of musical structure in the light of music psychology. Roczniki Psychologiczne [Annals of Psychology], 22(2), 121-134. doi: 10.18290/rpsych.2019.22.2-2

Psychology of Music. (2019). Journal aim and scope. Retrieved from https://uk.sagepub.com/en$\mathrm{gb} /$ eur/journal/psychology-music\#aims-and-scope

Rakowski, A. (1990). Intonation variants of musical intervals in isolation and in musical contexts. Psychology of Music, 18(1), 60-72. https://doi.org/10.1177/0305735690181005

Rakowski, A. (2001). What is music? Musicae Scientiae, 5(2_suppl), 125-130. https://doi.org/ $10.1177 / 10298649010050$ S217

Rakowski, A., \& Rogowski, P. (2011). Absolute pitch and its frequency range. Archives of Acoustics, 36(2), 251-266. https://doi.org/10.2478/v10168-011-0020-1

Rentfrow, P. J., \& Gosling, S. D. (2003). The do re mi's of everyday life: The structure and personality correlates of music preferences. Journal of Personality and Social Psychology, 84(6), 1236-1256. https://doi.org/10.1037/0022-3514.84.6.1236

Schäfer, K., \& Eerola, T. (2018). How listening to music and engagement with other media provide a sense of belonging: An exploratory study of social surrogacy. Psychology of Music. https://doi.org/10.1177/0305735618795036

Schäfer, T., Sedlmeier, P., Städtler, C., \& Huron, D. (2013). The psychological functions of music listening. Frontiers in Psychology, 4. https://doi.org/10.3389/fpsyg.2013.00511

Schellenberg, E. G. (2006). Exposure to music: The truth about the consequences. In G. E. McPherson (Ed.), The child as musician: A handbook of musical development (pp. 111134). Oxford: Oxford University Press.

Schlaug, G. (2008). Music, musicians, and brain plasticity. In S. Hallam, I. Cross, \& M. Thaut (Eds.), The Oxford handbook of music psychology. Oxford: Oxford University Press. 
Sloboda, J. A. (2002). Umyst muzyczny: Poznawcza psychologia muzyki [The musical mind. The cognitive psychology of music]. Warsaw: The Fryderyk Chopin Academy of Music.

Swaminathan, S., \& Schellenberg, E. G. (2015). Current emotion research in music psychology. Emotion Review, 7(2), 189-197. https://doi.org/10.1177/1754073914558282

Thaut, M. (2016). History and research. In S. Hallam, I. Cross, \& M. Thaut (Eds.), The Oxford handbook of music psychology ( $2^{\text {nd }}$ ed., pp. 893-904). Oxford: Oxford University Press.

The Really Useful Group. (2016). Facts and figures. The Phantom of the Opera. Retrieved June 28, 2019, from The Phantom of the Opera website: https://www.thephantomoftheopera.com/ facts-figures/

Wertheimer, M. (2012). A brief history of psychology ( $5^{\text {th }}$ ed.). New York: Psychology Press Taylor $\&$ Francis Group.

Zielinska, H., \& Miklaszewski, K. (1992). Memorising two melodies of different style. Psychology of Music, 20(2), 95-111. https://doi.org/10.1177/0305735692202001 